\title{
Field Tests for Cucumber Resistance to Gummy Stem Blight in North Carolina
}

\author{
Todd C. Wehner ${ }^{1}$ and Paul C. St. Amand ${ }^{2}$ \\ Department of Horticultural Science, Box 7609, North Carolina State \\ University, Raleigh, NC 27695-7609 \\ Additional index words. Ascochyta cucumis, Colletotrichum orbiculare, Cucumis anguria, \\ Cucumis myriocarpus, Cucumis sativus, Cucumis zeyheri, Cucurbitaceae, Didymella \\ bryoniae, disease resistance, Mycosphaerella citrullina, Mycosphaerella melonis, Phoma \\ cucurbitacearum, Phyllosticta cucurbitacearum, vegetable breeding
}

\begin{abstract}
Gummy stem blight [Didymella bryoniae (Auersw.) Rehm] is the second most important pathogen of field-grown cucumbers (Cucumis sativus L.) in North Carolina and a severe problem for greenhouse-grown cucumbers worldwide. To determine whether resistance exists under North Carolina field conditions, 83 cultigens [cultivars, breeding lines, and plant introduction (PI) accessions] were evaluated in the field for 4 years for their resistance to a mixture of $D$. bryoniae isolates. Plants were inoculated at the vine tip-over stage and rated for foliar lesion size and number. Cultigens identified as resistant in Wisconsin and The Netherlands were not resistant in North Carolina. When averaged over years and locations, the most resistant $C$. sativus cultigens were PI 164433, 'Slice', PI 390264, M 17, and M 12. Several accessions of related Cucumis species were highly resistant: PI 299568 (C. myriocarpus Naud.), PI 282450 (C. zeyheri Sond.), PI 299572 (C. myriocarpus), and PI 233646 (C. anguria L.). The most susceptible cultivars were 'Colet', 'Meresto', 'Supergreen', 'Dura', 'Pioneer', 'Marketmore 76', 'Pickmore', and 'Addis'. 'Calypso' and 'Dasher II', popular cultivars in North Carolina, were moderately susceptible.
\end{abstract}

Gummy stem blight of cucumber is caused by Didymella bryoniae [synonyms: Mycosphaerella citrullina (C.O. Sm.) Gross. and Mycosphaerella melonis (Pass.) Chiu and Walker] and its anamorph Phoma cucurbitacearum (Fr.: Fr.) Sacc. (Farr et al., 1989) (synonyms: Ascochyta cucumis Fautr. and Roum. and Phyllosticta cucurbitacearum Sacc.). Didymella blight and phoma blight have similar symptoms and control practices and are referred to as gummy stem blight. Gummy stem blight causes severe defoliation in late production stages and is the second most important cucumber pathogen in North Carolina, following the root-knot nematode (St. Amand and Wehner, 1991). Gummy stem blight is a serious disease of greenhouse-grown cucumbers in The Netherlands, where it causes fruit rot (Van Steekelenburg, 1985a). Chemical control is available but is ineffective under certain environmental conditions, such as extended rainy periods. Genetic resistance is usually less affected by environmental conditions than chemical control and is preferable to reduce pesticide inputs.

Received for publication 22 May 1992. Accepted for publication 14 Dec. 1992. Research was supported in part by a grant from the North Carolina Pickle Producers Assn. We gratefully acknowledge the research advice of the late Samual F. Jenkins, Jr., and the technical assistance of R.R. Horton, Jr. Thanks to William Van Der Arend, Nunhems Zaden, for supplying breeding lines that were tested. The cost of publishing this paper was defrayed in part by the payment of page charges. Under postal regulations, this paper therefore must be hereby marked advertisement solely to indicate this fact.

'Professor.

${ }^{2}$ Graduate Assistant
Disease severity was increased by volatile compounds contained in Cucumis spp. and Cucurbita spp. (Pharis et al., 1982). Cucumber beetles (Diabrotica undecimpunctata howardi Barber and Acalymma vittatum Fabricus) and powdery mildew [Erysiphe cichoracearum DC. or Sphaerotheca fuliginea (Schlect.) Poll.] may predispose the plant to infection or contribute to disease spread (Bergstrom et al., 1982). Infection caused by $D$. bryoniae seemed to depend on relative humidity, with more infection occurring at $95 \%$ than at $50 \%$. The most severe infection was produced by freestanding water on leaves. Wounding was essential for infection of older leaves (Van Steekelenburg, 1985b). More lesions on the fruit and main stem were also apparent in plants that were grown for extended periods in high humidity or with free water on fruit (Van Steekelenburg, 1985a).

Using field screening methods in Wisconsin, 'Homegreen \#2' and plant introduction (PI) 200818 were reported to be resistant (Wyszogrodzka et al., 1986). In The Netherlands, greenhouse screening methods were used to identify several PI accessions as resistant, including PI 200818 (Van Der Meer et al., 1978). In Dutch greenhouse trials, several breeding lines were identified as resistant (William Van Der Arend, Nunhems Zaden, personal communication).

The objective of this study was to evaluate pickling and slicing cucumbers, including cultigens identified as resistant in Wisconsin and The Netherlands, for resistance to gummy stem blight under North Carolina field conditions.

Field tests were run in 1981, 1982, 1983, and 1986 . In 1981, we evaluated 1165 culti- gens (PI accessions, breeding lines, cultivars, and related Cucumis spp.) available in the U.S. Dept. of Agriculture and North Carolina State Univ. germplasm collections. The most resistant and most susceptible cultigens were chosen from the 1981 test for further study. Additional cultigens were examined in 1983 and 1986 to duplicate the results of studies done in The Netherlands and include standard cultivars as controls. 'Homegreen \#2', which was identified as resistant in Wisconsin, was not available at the time of testing and was reported to be resistant after our research was completed.

Plants in field plots were rated for foliar lesions using a scale, where $0=$ no foliar symptoms, 1 to $2=$ trace, 3 to $4=$ slight, 5 to $6=$ moderate, 7 to $8=$ advanced, and $9=$ plant dead. The rating system was modeled after the categories developed by Thompson and Jenkins (1985). In 1984, after inoculation and irrigation were applied, plants failed to develop disease due to an apparently unfavorable environment.

Plots were inoculated with an equal number of spores from $12 \mathrm{D}$. bryoniae isolates. Also, noninoculated fields near the tests usually had a high incidence $(\approx 80 \%)$ of gummy stem blight. Plants were sprayed at the vine tip-over stage (four to six true leaves) to runoff using a back-pack sprayer (Solo, Newport News, Va.) at 103 to $138 \mathrm{kPa}$ (15 to $20 \mathrm{psi}$ ). Overhead irrigation was used (25 to 38 $\mathrm{mm} \cdot$ week $^{-1}$ ) to spread the inoculum and encourage uniform disease development. Every third row (fourth row in 1986) was planted with susceptible Wisconsin SMR 18 to enhance the uniformity of disease spread.

Inoculum preparation. Twelve $D$. bryoniae isolates, collected from cucumber fields in Arizona, Florida, North Carolina, and Wisconsin, were increased on petri plates containing $10 \mathrm{ml}$ of malt extract agar using mycelial plug inoculation. Inoculated plates were incubated for 10 days at $24 \pm 2 \mathrm{C}$ under alternating periods of $12 \mathrm{~h}$ of fluorescent light (40 to 90 $\mu \mathrm{mol} \cdot \mathrm{m}^{-2} \cdot \mathrm{s}^{-1}$ photosynthetic photon flux) and $12 \mathrm{~h}$ of darkness, which promoted the formation of spore-producing pycnidia. Inoculum was prepared by flooding plates with $15 \mathrm{ml}$ of sterile distilled water, scraping the surface of the agar with a rubber spatula, and collecting the liquid. The spore suspension was standardized to a concentration of $1 \times 10^{6}$ spores $/ \mathrm{ml}$ using a hemacytometer and kept at $5 \mathrm{C}$ for $\approx 15$ $h$ until use. The surfactant Tween- 80 was added $\left(0.5 \mathrm{ml} \cdot\right.$ liter $\left.^{-1}\right)$ to the spore suspension before inoculating plants.

Experiment design. Plots were $6 \mathrm{~m}$ long (1981) with 40 plants each or $3 \mathrm{~m}$ long (1982, 1983, 1986) with 30 plants each and planted on raised, shaped beds $1.5 \mathrm{~m}$ apart (center to center) and separated at each end by $1.5-\mathrm{m}$ alleys. Guard rows surrounded each test. Standard cultural practices were used for crop production (Hughes et al., 1983).

A randomized complete-block design was used for all tests. Each test was conducted at the Horticultural Crops Research Station, Clinton, N.C., with three (1982) or six (1983, 1986) replications, except for the 1981 test, 
which was conducted at the Horticultural Crops Research Station, Castle Hayne, N.C., without replication. For each plot, one rating was given 7,14 , and 21 days after inoculation, except in 1981, when ratings were given only 7 days after inoculation. The 1981 test was treated as a germplasm survey to identify cultigens to use in further resistance studies.

Data were analyzed using PROC GLM (for analysis of variance) and PROC STANDARD from SAS (SAS Institute, Cary, N.C.). As expected, cultigens changed rank over years andlocations (e.g., M 12 and M 17 in Table 1). Most changes in rank generally were not large. To reduce variability over years and locations, data for each environment were standardized to a mean of 4.5, SD 1.5. However, this procedure resulted in greater changes in rank for most cultigens (data not presented) than actual (not standardized) means; therefore, the latter are presented (Table 1).

Cultigens were ranked on mean rating over years and locations. Analysis of variance was used to test treatment effects. Mean separations were performed using Fisher's LSD. The 1981 test was conducted as a germplasm survey to identify cultigens that would be useful for further testing. Therefore, only the most resistant and most susceptible cultigens from the 1165 tested were used in subsequent tests. Due to the large number of cultigens examined in 198 1, only one plot (without replication) of each cultigen was tested, therefore, cultigen rank for that test should not be interpreted as a final rank (Table 1).

All 11 accessions belonging to related species (C. africanus L. f., C. anguria, $C$. dipsaceus Ehrenb. ex. Spach, C. ficifolius A. Rich., $C$. myriocarpus, and C. zeyheri) tested in the 1981 field screening were highly resistant. In the 1981 and 1982 field tests, the four most resistant related Cucumis spp. were (in order of resistance): PI 299568 (C. myriocarpus), PI 282450 (C. zeyheri), PI 299572 (C. myriocarpus), and PI 233646 (C. anguria) (Table 1). However, none of those species (or any others) is sexually compatible with $C$. sativus.

In the 1983 field test, 'Slice', 'Commanche 7', 'Poinsett 76', M 17, and 'Tablegreen' were the most resistant cultigens; in 1986, 'Slice', 'Poinsett 76', and M 12 were the most resistant. When averaged over years and locations, no $C$. sativus cultigens were as resistant as the related Cucumis spp. tested in 1981 and 1982 (Table 1). 'Calypso' pickle and 'Dasher II' slicer, cultivars commonly grown in North Carolina, were moderately susceptible in all tests, as expected. 'Addis' was susceptible in the 1982 and 1983 tests, but was less susceptible in the 1986 test, possibly because cultigen means had a small range (3.6-7.2) for the test in 1986. PI 164433, 'Slice', PI 390264, M 17 , and M 12 were the most resistant cucumber cultigens over years and locations. The most susceptible cultivars were 'Colet', 'Meresto', 'Supergreen', 'Dura', 'Pioneer', 'Marketmore 76', 'Pickmore', and 'Addis' (Table 1). Several breeding lines from Nunhems Zaden, RS 78038, and PI 351139 were the most susceptible of all cultigens tested.
Table 1. Resistance of 83 cultigens of Cucumis sativus (unless otherwise specified) to foliar symptoms of gummy stem blight in inoculated fields during 1981 at Castle Hayne, N.C., and 1982, 1983, and 1986 at Clinton, N.C. (cultigens ranked by mean rating).

\begin{tabular}{|c|c|c|c|c|c|c|}
\hline \multirow{2}{*}{ Rank, cultigen } & \multirow{2}{*}{$\begin{array}{c}\text { Seed } \\
\text { source }\end{array}$} & \multicolumn{5}{|c|}{ Disease test ratings $(0-9)^{2}$} \\
\hline & & 1981 & 1982 & 1983 & 1986 & Mean \\
\hline \multicolumn{7}{|l|}{$1 \quad$ PI 299568} \\
\hline (C. myriocarpus) & South Africa & 1.5 . & 0.8 & --- & --- & 1.2 \\
\hline \multicolumn{7}{|l|}{2 PI 282450} \\
\hline (C. zeyheri) & South Africa & 1.7 & 0.8 & -.. & --- & 1.2 \\
\hline 3 PI 299572 & & & & & & \\
\hline (C. myriocarpus) & South Africa & 2.5 & 0.3 & ... & ... & 1.4 \\
\hline \multicolumn{7}{|l|}{4 PI 233646} \\
\hline (C. anguria) & Ethiopia & 1.5 & 1.5 & ... & --- & 1.5 \\
\hline 5 PI 164433 & India & 1.5 & 2.2 & --- & $\ldots$ & 1.8 \\
\hline 6 Slice & Clemson Univ. & 2.5 & 2.5 & 2.9 & 3.6 & 2.9 \\
\hline 7 PI 390264 & Japan & 2.5 & 3.7 & --- & --- & 3.1 \\
\hline 8 M 17 & North Carolina State Univ. & 2.5 & 1.7 & 4.1 & 4.4 & 3.2 \\
\hline $9 \quad \mathrm{M} 12$ & North Carolina State Univ. & 1.5 & 2.7 & 4.8 & 4.1 & 3.3 \\
\hline 10 PSX 10780 & PetoSeed & 2.5 & 3.2 & 4.8 & --- & 3.5 \\
\hline 11 Commanche 7 & SunSeeds & -- & $\cdots$ & 3.5 & --- & $3.5^{y}$ \\
\hline 12 Clinton & North Carolina State Univ. & --- & 3.0 & 4.3 & --- & 3.6 \\
\hline 13 Ark $77-19 B$ & Univ. of Arkansas & 2.5 & 4.7 & --- & --- & 3.6 \\
\hline 14 Tablegreen & Rogers NK & --. & --- & 4.1 & --. & $4.1^{y}$ \\
\hline 15 PI 200818 & Burma & --- & 4.2 & --- & --- & $4.2^{y}$ \\
\hline 16 Poinsett 76 & Asgrow Seed & --- & 4.6 & 4.0 & 4.0 & 4.2 \\
\hline 17 PI 357858 & Former Yugoslavia & 2.5 & 6.0 & --. & -.. & 4.2 \\
\hline 18 PI 418962 & China & 2.5 & 6.0 &.-- & $\ldots$ & 4.2 \\
\hline 19 PI 432883 & China & 2.5 & 6.0 & --- & --. & 4.2 \\
\hline 20 WI 2757 & U.S. Dept. of Agr., Wisconsin & --- & --- & --- & 4.3 & $4.3^{y}$ \\
\hline 21 Cherokee 7 & SunSeeds & -.- & --- & 4.3 & -- & $4.3^{y}$ \\
\hline 22 PI 172838 & Turkey & 2.5 & 6.2 & --- & --- & 4.4 \\
\hline 23 PI 432893 & China & 1.5 & 7.4 & --- & --- & 4.4 \\
\hline 24 Chipper & Clemson Univ. & --. & --- & 4.3 & 4.5 & 4.4 \\
\hline 25 Lemon & Rogers NK & 2.5 & 7.0 & 4.8 & --- & 4.8 \\
\hline 26 Calico & North Carolina State Univ. & --. & -.. & 5.1 & 4.4 & 4.8 \\
\hline 27 Sumter & Asgrow Seed & -.. & --- & 4.9 & 4.9 & 4.9 \\
\hline $28 \mathrm{MSU} 5802 \mathrm{~A}$ & Michigan State Univ. & 3.4 & 8.4 & -- & -- & $5.0^{y}$ \\
\hline 29 Wautoma & U.S. Dept. of Agr., Wisconsin & --- & --- & --- & 5.1 & $5.1^{y}$ \\
\hline \multicolumn{7}{|l|}{30 Windermoor } \\
\hline Wonder & Stokes Seed & --- & --- & 5.1 & --- & $5.1^{y}$ \\
\hline 31 Slice Mor & Harris-Moran & -.- & -.- & 5.0 & 5.3 & 5.2 \\
\hline 32 Guardian & Rogers NK & --. & -.- & 4.8 & 5.5 & 5.2 \\
\hline 33 Dasher & PetoSeed & $\ldots$ & $\ldots$ & 5.2 & -.. & $5.2^{y}$ \\
\hline 34 Spartan Salad & Rogers NK & $\ldots$ & --- & 5.2 & --. & $5.2^{y}$ \\
\hline 35 Carolina & Rogers NK & --- & --- & 5.6 & 4.8 & 5.2 \\
\hline 36 Regal & North Carolina State Univ. & --- & --- & 5.1 & 5.4 & 5.2 \\
\hline 37 Ashley & Asgrow Seed & --- & --- & 4.8 & 5.7 & 5.2 \\
\hline 38 Calypso & Asgrow Seed & --- & --- & 5.4 & 5.2 & 5.3 \\
\hline 39 Raider & Harris-Moran & --- & --- & 5.3 & 5.6 & 5.4 \\
\hline 40 Palomar & Asgrow Seed & --- & --- & 4.9 & 6.0 & 5.4 \\
\hline 41 Dasher II & PetoSeed & --- & --- & --- & 5.5 & $5.5^{y}$ \\
\hline 42 Cypress & Ferry-Morse & --- & --- & 5.2 & 5.8 & 5.5 \\
\hline 43 Marketer & Ferry-Morse & --- & --- & 5.3 & 5.8 & 5.6 \\
\hline 44 Castlepik & SunSeeds & --- & --- & 5.1 & 6.0 & 5.6 \\
\hline 45 Bush Champion & Burpee Seed & --- & --- & 5.0 & 6.1 & 5.6 \\
\hline 46 Triple Crown & Ferry-Morse & --- & --- & 5.8 & 5.4 & 5.6 \\
\hline 47 Pacer & Harris-Moran & --- & --- & 5.2 & 6.0 & 5.6 \\
\hline 48 Pikmaster & Rogers NK & --. & --- & 5.6 & 5.7 & 5.6 \\
\hline 49 Verino & Sluis \& Groot & --- & $\ldots$ & 5.5 & 5.8 & 5.6 \\
\hline 50 Wis. SMR 18 & Univ. of Wisconsin & -.- & 5.0 & 5.6 & 6.6 & 5.7 \\
\hline \multicolumn{7}{|l|}{51 National } \\
\hline Pickling & SunSeeds & --- & --- & 5.7 & --- & $5.7^{y}$ \\
\hline 52 PI 103049 & China & 7.0 & 4.7 & --- & --- & 5.8 \\
\hline 53 PI 339241 & Turkey & 6.0 & 5.5 & --- & $\ldots$ & $5.8^{y}$ \\
\hline 54 Straight 8 & Rogers NK & -.- & $\ldots$ & 5.8 & 5.9 & 5.8 \\
\hline 55 Earlipik 14 & Rogers NK & --- & --- & 5.4 & 6.3 & 5.8 \\
\hline 56 Coolgreen & Asgrow Seed & --- & --- & 5.6 & 6.6 & 6.1 \\
\hline 57 NZ 99695 & Nunhems Zaden & --- & 6.2 & --- & --- & $6.2^{y}$ \\
\hline 58 Addis & North Carolina State Univ. & --- & 8.3 & 6.2 & 4.5 & 6.3 \\
\hline 59 PI 257487 & China & 8.5 & 4.5 & --- & --- & 6.5 \\
\hline $60 \mathrm{NZ} 99702^{\mathrm{x}}$ & Nunhems Zaden & -- & 6.5 & --- & --- & $6.5^{y}$ \\
\hline 61 Pickmore & Harris-Moran & 8.5 & 5.5 & 5.7 & --- & 6.6 \\
\hline 62 Marketmore 76 & Cornell Univ. & -.- & 9.0 & 5.3 & 5.5 & 6.6 \\
\hline 63 Pioneer & Rogers NK & 8.5 & 6.8 & 5.1 & 6.1 & 6.6 \\
\hline 64 NZ $99715^{x}$ & Nunhems Zaden & $\ldots$ & 6.7 & --. & -.. & $6.7^{y}$ \\
\hline 65 PI 172848 & Turkey & 8.0 & 5.7 & -- & --- & 6.8 \\
\hline
\end{tabular}


Table 1. Continued.

\begin{tabular}{|c|c|c|c|c|c|c|}
\hline \multirow[b]{2}{*}{ Rank, cultigen } & \multirow{2}{*}{$\begin{array}{c}\text { Seed } \\
\text { source }\end{array}$} & \multicolumn{5}{|c|}{ Disease test ratings $(0-9)$} \\
\hline & & 1981 & 1982 & 1983 & 1986 & Mean \\
\hline 66 Dura & Rijk Zwaan & 9.0 & 7.8 & 5.8 & 6.0 & 7.2 \\
\hline 67 Meresto & Nunhems Zaden & 8.5 & 7.5 & 5.6 & --- & 7.2 \\
\hline 68 Supergreen & Harris-Moran & -- & - & -- & 7.2 & $7.2^{y}$ \\
\hline 69 NZ 99712x & Nunhems Zaden & -- & 7.3 & --- & -- & $7.3^{y}$ \\
\hline 70 PI 137848 & Iran & 8.5 & 6.3 & --- & --- & 7.4 \\
\hline $71 \mathrm{NZ} 99721^{x}$ & Nunhems Zaden & -- & 7.6 & --- & --- & $7.6^{y}$ \\
\hline 72 PI 174177 & Turkey & 8.0 & 7.3 & --- & --- & 7.6 \\
\hline 73 PI 274902 & Great Britain & 8.5 & 6.8 & --- & -- & 7.6 \\
\hline 74 PI 360939 & Netherlands & 8.0 & 7.7 & --- & -- & 7.8 \\
\hline 75 PI 205995 & Sweden & 8.5 & 7.5 & --- & --- & 8.0 \\
\hline 76 Colet & Royal Sluis & 8.5 & 8.5 & 8.2 & 7.1 & 8.1 \\
\hline 77 NZ 626B-76x & Nunhems Zaden & 8.5 & 7.7 & -- & -- & 8.1 \\
\hline $78 \mathrm{NZ} \mathrm{87195^{ \textrm {x } }}$ & Nunhems Zaden & 8.5 & 8.3 & --- & --- & 8.4 \\
\hline 79 NZ 99722x & Nunhems Zaden & -- & 8.6 & --- & --- & $8.6^{y}$ \\
\hline 80 RS 78038 & Royal Sluis & 8.5 & 8.8 & --- & -- & 8.6 \\
\hline 81 NZ 99725 & Nunhems Zaden & -- & 8.7 & --- & --- & $8.7^{y}$ \\
\hline 82 NZ 87197x & Nunhems Zaden & 9.0 & 8.8 & -- & -- & 8.9 \\
\hline 83 PI 351139 & Former Soviet Union & 9.0 & 9.0 & --- & --- & 9.0 \\
\hline $\operatorname{LSD}(P \leq 0.05)$ & & 1.6 & 1.0 & 0.4 & 0.4 & 0.6 \\
\hline Mean & & 5.2 & 5.8 & 5.1 & 5.5 & 5.5 \\
\hline Minimum & & 1.5 & 0.3 & 2.9 & 3.6 & 1.2 \\
\hline Maximum & & 9.0 & 9.0 & 8.2 & 7.2 & 9.0 \\
\hline cv $(\%)$ & & 62 & 42 & 16 & 16 & 33 \\
\hline
\end{tabular}

${ }^{2}$ Rated for foliar lesions on a 0 to 9 scale $(0=$ no foliar symptoms, $1-2=$ trace, $3-4=$ slight, $5-6=$ moderate $7-8=$ advanced, $9=$ plant dead). Data are for one rating without replication in 1981 , means of three ratings of three replications in 1982, and means of three ratings of six replications in 1983 and 1986.

'Indicates cultigens tested in 1 year only.

Indicates gummy stem blight-resistant cultigens from a Dutch breeding program.

Eight cultigens comprise a useful set of standards for testing resistance to gummy stem blight in the field: PI 299568 and PI 164433 (resistant), 'Slice' and M 17 (moderately resistant), 'Coolgreen' and 'Marketmore 76' (moderately susceptible), and 'Supergreen' and PI 351139 (susceptible).

All of the breeding lines reported as resistant in Dutch greenhouse trials (W. Van Der Arend, Nunhems Zaden, personal communication) were susceptible or very susceptible in field studies in North Carolina (Table 1). PI 2008 18, reported as resistant in Wisconsin and The Netherlands, was moderately resistant in the 1982 test (Table 1); however, it was not as resistant as PI 164433, 'Slice', PI 390264, M 17 , or M 12 in the same test (Table 1). Possibly, PI 200818 was not homogeneous for resistance to gummy stem blight, a fact that could account for observed differences in resistance over environments. PI 339241, which was reported to be resistant in The Netherlands (Van Der Meer et al., 1978), was susceptible in our tests. 'Homegreen \#2', also identified as resistant in Wisconsin, was not tested. Variability over environments also may be due to differences in fungal isolates or to isolate $\mathrm{x}$ environment interactions. Variability in virulence has been reported (Van Steekelenburg, 1982). However, it is not known if true $D$. bryoniae races exist. Another possibility for the differing reactions between our tests and others is that our inoculations used several $\boldsymbol{D}$. bryoniae isolates, while other tests used only one (Van Der Meer et al., 1978; Wyszogrodzka et al., 1986). The cultigens from Nunhems Zaden were selected for resistance under Dutch greenhouse conditions. Their lack of resistance may have been due to a poor correlation between field and greenhouse reaction, which has been demonstrated in some of our studies (St. Amand and Wehner, unpublished data) and by Wyszogrodzka et al. (1986). Additional studies are needed to determine the important environmental factors controlling resistance.

The coefficient of variability for gummy stem blight ratings varied over environments from $16 \%$ to $62 \%$. Also, anthracnose [Colletotrichum orbiculare (Berk. and Mont.) Arx] lesions on the plants in 1983 made it more difficult to rate gummy stem blight. There may have been an interaction between the two diseases. However, it is difficult to keep anthracnose out of field tests, since gummy stem blight and anthracnose occur naturally at about the same time in North Carolina cucumber production areas.

Seedling tests for gummy stem blight may be sufficiently reliable as a preliminary selection tool in breeding programs, but field testing will be necessary in later stages. The occurrence of other diseases in field tests may not be a problem for breeding programs, since resistance usually is evaluated for all major diseases in each stage.

In summary, resistance to gummy stem blight under North Carolina field conditions was found among the cucumber cultigens tested. PI 164433, 'Slice', PI 390264, M 17, and M 12 offer a usable level of resistance for plant breeders interested in developing improved cultivars. Cultigens resistant in The Netherlands and Wisconsin were not resistant in North Carolina, a result that may be due to differences in pathogen or environment-subjects for future studies. Developing a rapid and accurate greenhouse screening method or detached leaf test with good correlation to field tests would facilitate selecting resistant cultigens.

\section{Literature Cited}

Bergstrom, G.C., D.E. Knavel, and J. Kuc'. 1982. Role of insect injury and powdery mildew in the epidemiology of the gummy stem blight disease of cucurbits. Plant Dis. 66:683-686.

Farr, D.F., G.F. Bills, G.P. Chamuris, and A.Y. Rossman. 1989. Fungi on plants and plant products in the U.S. Amer. Phytopathol. Soc., St. Paul, Minn.

Hughes, G.R., C.W. Averre, and K.A. Sorensen. 1983. Growing pickling cucumbers in North Carolina. N.C. Agr. Ext. Serv. AG-315.

Pharis, V.L., T.R. Kemp, and D.E. Knavel. 1982. Host plant-emitted volatiles as a factor in susceptibility in vitro of Cucumis and Cucurbita spp. to the fungus Mycosphaerella melonis. Scientia Hort. 17:311-317.

St. Amand, P.C. and T.C. Wehner. 1991. Crop loss to 14 diseases of cucumber in North Carolina from 1983 to 1988. Cucurbit Genet. Coop. Rpt. 14:15-17.

Thompson, D.C. and S.F. Jenkins. 1985. Pictorial assessment key to determine fungicide concentrations that control anthracnose development on cucumber cultivars with varying resistance levels. Plant Dis. 69:833-836.

Van Der Meer, Q.P., J.L. Van Bennekom, and A.C. Van Der Giessen. 1978. Gummy stem blight resistance of cucumbers (Cucumis sativus L.). Euphytica 27:861-864.

Van Steekelenburg, N.A.M. 1982. Factors influencing external fruit rot of cucumber caused by Didymella bryoniae . Neth. J. Plant Pathol. 88:4756.

Van Steekelenburg, N.A.M. 1985a. Influence of time of transition from night to day temperature regimes on incidence of Didymella bryoniae and influence of the disease on growth and yield of glasshouse cucumbers. Neth. J. Plant Pathol. 91:225-233.

Van Steekelenburg, N.A.M. 1985b. Influence of humidity on incidence of Didymella bryoniae on cucumber leaves and growing tips under controlled environmental conditions. Neth. J. Plant Pathol. 91:277-283.

Wyszogrodzka, A.J., P.H. Williams, and C.E. Peterson. 1986. Search for resistance to gummy stem blight (Didymella bryoniae) in cucumber (Cucumis sativus L.). Euphytica 35: 603-613. 